STUDIA UKRAINICA POSNANIENSIA, vol. II: 2014, pp. 91-101. ISBN 978-83-936654-5-7. ISSN 2300-4754.

\title{
ПОЛЯк ЯК „ІНШИЙ” В УКРАЇНСЬКІЙ ІСТОРИЧНІЙ ПРОЗІ 1880-1890 РОКІВ
}

\author{
ОЛЕКСАНДР КИРИЛЬЧУК
}

Рівненський державний гуманітарний університет, Рівне - Україна

\author{
POLAK JAKO ,INNY” \\ W UKRAIŃSKEJ PROZIE HISTORYCZNEJ LAT 1880-1890 \\ OLEKSANDR KYRYLCZUK \\ Rówieński Państwowy Humanitarny Uniwersytet, Równe - Ukraina
}

\begin{abstract}
STRESZCZENIE. W artykule została poddana analizie reprezentacja obrazu Polaka jako „Innego” w prozie historycznej Iwana Neczuja-Łewyćkiego, Danyła Mordowcia oraz Mychajła Staryćkiego. Autor bada strategię modelowania literackich heteroobrazów, która ma ścisły związek ze strategią antykolonialną literatury ukraińskiej XIX wieku.
\end{abstract}

\author{
THE POLE AS THE „OTHER” \\ IN UKRAINIAN HISTORICAL PROSE IN 1880-1890 \\ OLEKSANDR KYRYLCHUK \\ Rivne State University of Humanities, Rivne - Ukraine
}

ABSTRACT. The article emphasizes the image of a Pole as „other” representation in the historical prose of Nechuy-Levitskiy, Mordovets and Starytskiy. The author examines the modeling strategies of heteroimages in which the "othering" of Poles collective images is connected with the anticolonial strategy of Ukrainian literature of the late 19th century.

$\mathrm{B}$ українській літературі другої половини XIX століття формуються нові проекти репрезентації образів власного Я та Іншого. Особливий масштаб реалізації цих стратегій пов'язаний з історичною прозою 1880 1890-х років, в якій художне інтерпретування минулого безпосередньо оприявлювало моделі літературного сприйняття етнообразів представників сусідніх національних груп.

Українська історична проза кінця XIX століття (Данило Мордовець, Михайло Старицький, Іван Нечуй-Левицький) набуває особливого концептуального наповнення в силу трансформації світоглядної та естетичної аксіологічної системи вітчизняного письменства. У ситуації національної розпорошеності література відігравала роль ключового елемента у формуванні відчуття етнічної та культурної окремішності українства у російській імперській системі. Історична белетристика 1880-1890-х років демонструє своєрідний варіант 
формування національної пам'яті та віднайдення національної тожсамості через занурення у буремне минуле.

Образ Іншого в українській історичній прозі XIX ст. тісно пов'язаний з інтерпретацією історичних подій XVII ст., де ключовими і визначними обставинами $\epsilon$ міжнаціональні мілітарні конфлікти (польсько-українська війна 1648-1657 років). Ентоні Д. Сміт зазначає, що саме довготривалі воєнні протистояння між різними етносами „мобілізують і зводять докупи представників різних етнічних прошарків і забезпечують матеріал для героїчних міфів

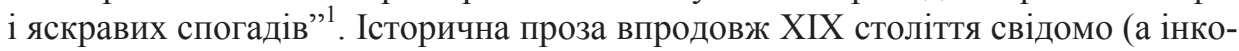
ли і несвідомо), опираючись на художнє осмислення саме вітчизняного воєнного досвіду XVII-XVIII ст., намагається вибудувати символізований простір пробудження чуття колективної національної єдності української спільноти. Апелювання до доколоніальної історичної пам'яті автономізує українську етнічну окремішність у загальноімперському наративі через призму протиставлення військової потуги українського козацтва мілітаризованим об'єднанням інших націй.

Загалом в українській і польській історичній романістиці спостерігається глорифікація мілітарного аспекту власного етнообразу, а почасти і яскрава негація Іншого як супротивника та ворога. Власне бінарна модель „своє” - „чуже" найкраще надається в українській історичній белетристиці 1880-1890-х років для окреслення проекту національної ідентичності, оскільки відштовхування від образу Іншого увиразнює особливості власного етносу. У вітчизняному історичному романі XIX віку автори у переважній більшості звертаються до осмислення подій XVII ст., тобто періоду Хмельниччини в Україні, а відтак у центрі літературних версій минулого постають польсько-українські взаємини. Таким чином, в історичній прозі $1880-1890$-х років домінуючим виступає моделювання гетерообразу поляка, а представники інших етносів набагато менш виразно представлені в українській прозі, присвяченій художньому інтерпретуванню минулого. Так, образ росіянина не набув настільки значного обширу, як у випадку поляків. В українському історичному наративі росіяни посідають місце не безпосереднього учасника міжнаціонального конфлікту, а швидше сприймаються як певні спостерігачі. Найчастіше представники російської нації в історичній прозі Мордовця, Нечуя-Левицького та Старицького зображені в іпостасі дипломата або царського представника при гетьманському чи козацькому уряді. I в одному, і в другому випадку він - боярин, і саме так постає своєрідним репрезентантом російськості в українській історичній белетристиці.

Втім, в українській історичній прозі у питанні репрезентації представників сусідніх націй варто враховувати і колоніальний вплив імперського дискурсу на літературні версії минулого. Українська культура у XIX столітті

\footnotetext{
${ }^{1}$ Е н т о н і Д. С м і т, Культурні основи націй. Іерархія, заповіт і республіка. Наукове видання, переклад з англійської П. Таращука, Київ 2009, с. 53.
} 
опиняється у ситуації між Сциллою і Харибдою: з одного боку, відчувається потужний імперський вплив російського „центру”, що і на мистецькому, і на суспільно-політичному рівнях примітивізує українську спільноту, позбавляючи iï перспектив будь-якого національно-культурного самоокреслення поза метропольною матрицею; 3 другого - українська гуманітаристика піддається колоніальному впливу зі сторони польської культури, принаймні у сенсі осмислення власної присутності на спільній для поляків і українців території. Така проекція не є типовою для класичного варіанту постколоніальної критики, оскільки Польщу важко сприймати як імперію, адже впродовж XIX століття вона перебувала у такому ж бездержавному стані, як і Україна. Хоча можна стверджувати про певні світоглядні та інтелектуальні стратегії сприйняття українства як частини загальнопольського культурного та державного проекту. Алєксандер Ф'ют, розглядаючи проблему наявності колоніальних тенденцій в польському письменстві, зазначає, що

[...] був в історії Польщі певний період, коли не вона являла собою терен експансії, але сама таку експансію вчиняла. Що то іiі культура витиснула на маргінес місцеві культури ${ }^{2}$.

Польська домінація залишалася на обширах колишньої Речі Посполитої і після втрати нею державності та розподілу польських земель між трьома „сильними сусідами” - Росією, Прусією і Австро-Угорщиною. Своєрідний літературний „імперський дискурс” витворює на „кресовій” території проект напіворієнталізації, у якому Орієнт корелюється із Україною, наділяючи іiі відповідними ознаками екзотичної принадності та цивілізаційної відсталості. Для польської культури XIX-XX ст. поняття „кресів” постає свого роду варіантом „дискурсу знання і влади, що полягає в утвердженні мітів і управлінні колективною уявою, а також емоціями".

Українська історична проза другої половини XIX ст. набуває певного апелятивного спрямування проти культурного домінування польської та російської культур. Конструювання образу Іншого в історичній площині увиразнює стратегії контр-дискурсивного спротиву експансіоністським проектам сусідніх культур. Відтак моделювання гетерообразів в українській белетристиці Нечуя-Левицького, Старицького, Мордовця почасти опирається на антиколоніальний наратив, що у випадку протистояння польській культурі набирає відкритих форм, а щодо російської - латентних. Окрім того, контрдискурсивні практики подекуди корелюються з імперськими моделями репрезентації Іншого. Так, тексти Данила Мордовця (Царь и гетман, 1880) та Михайла Старицького (трилогія Богдан Хмельниикий, 1895-1897) були легально надруковані у свій час в Росії, а, значить, у загальному відповідали метро-

${ }^{2}$ А. Ф' ю т, Зустрічі з Іншим, переклад з польської Я. Поліщука, Акта 2009, с. 30.

${ }^{3}$ Б. Б а к у л а, Креси без взаємних викреслювань, переклад 3 польської Л. Головатої, [в:] „Критика” 2010, № 1-2, с. 20. 
польним ідеологічним моделям інтерпретації історичних наративів. Зокрема, акцентується увага на яскравій антипольській спрямованості української історичної белетристики, що, з одного боку, відбиває колоніальне ставлення „центру” (Російської імперії) до непокірної „периферії” (Польщі), а з другого, - співпадає із національною традицією, що склалася впродовж XVII - першої половини XIX століть. Власне російськомовність творів Данила Мордовця (Царь и гетман) та Михайла Старицького (трилогія Богдан Хмельниикий) також частково ілюструє переплетення метропольного та антиколоніального дискурсів щодо осмислення образу Іншого в українській історичній прозі кінця ХІХ століття.

Моделі негативної стереотипізації образу поляка формуються ще в козацьких літописах XVIII ст., у яких домінуючими постають релігійно-соціальні фактори конструювання Іншого. Так, Самійло Величко характеризуючи польсько-українські взаємини середини XVII ст., наголошує на тому, що

[...] поляки, маючи ще більшу, ніж раніше, заздрість і недоброхітство, почали великими податками й бідами обтяжувати й озлоблювати Русь, що була під їхньою владою, і козаків у самій Польщі та на Україні [... $]^{4}$.

Ще до більш контроверсійного маркування вдається Григорій Граб'янка, порівнюючи польське насилля над українцями із старозавітнім єгипетським поневірянням євреїв:

[...] и что бысть египе(т)ское озло(б)леніе [,] что мучителство фараоне (!) [,] противо лядскому тиранству [,]. Дътеи в котлахъ варяху [,] женамъ сосца древіемъ изгнътаху [,] и инная неисповъдимая творяху бъди [; $]^{5}$.

У подібній семіотичній матриці осмислює представників польської нації і анонімний автор Iсторії Русів, наголошуючи на їх знущаннях „над нещасним народом Руським”, що „перевершили міру щонайтемніших варварів ”6. Саме в літописній літературі формується своєрідний інтелектуальний стереотип щодо поляка як представника сили, що ставить собі за мету національне, соціальне та релігійне знищення всього українського.

Втім саме релігійний чинник набуває визначальних якостей в окресленні польської та української національних ідентичностей. Вітчизняна історіографічна традиція активно постулює православний маркер як ознаку національної окремішності українства від поляків, особливу роль у цьому контексті відіграють саме конфесійні утиски православ'я з боку католицизму. Так, український анонімний автор Iсторії Русів наголошує, що українська аристократія „не стерпівши наруг від Поляків”, „погодилось спершу на Унію, а опісля

\footnotetext{
${ }^{4}$ С. В е л и ч к о, Літопис, т. 1, Київ 1991, с. 40.

${ }^{5}$ Гисторія... Г. Граб'янки. Лћтописъ краткій, Житомир 2001, с. 68.

${ }^{6}$ Iсторія Русів, переклад І. Драча, Київ 1991. с. 80.
} 
навернулося зовсім на Католицтво Римське", точної денаціоналізації та розриву з українською нацією та ідентифікуванням себе із польською.

Українська історична проза 1880-1890-х років свідомо переймає „літописні” концептуальні підходи інтерпретування польсько-українських стосунків, аксіоматично потверджуючи їх. Однією із перших літературних версій абсолютизації релігійного фактора в іншуванні представників польської нації є Тарас Бульба $(1835,1842)$ Миколи Гоголя. Навіть у редакції 1835 року етнообраз поляка формується на яскраво негативному протиставленні православ'я та католицизму, де останній набуває демонічної конотації та сприймається як єретичний культ нехристиянського спрямування: „[...] нечистое католичество хочет, чтоб мы кинули и веру нашу христианскую $[\ldots]]^{\prime 8}$. Прикметно, що упереджене маркування західного християнства екстраполюється на увесь польський етнос, що в українській ситуації асоціювався у першу чергу із аристократією, шляхтою, тим самим зрівнюються релігійні та етнічні характеристики. Зрештою саме у тексті Миколи Гоголя складаються основні моделі релігійного іншування поляка, що згодом реалізуються і в українській історичній романістиці $1880-1890$-х років.

У трилогії Михайла Старицького Богдан Хмельниикий (1895-1897), окрім звичного потвердження про систематичні утиски католицькою польською шляхтою православного українства, детально акцентується увага на релігійній фанатичності Іеремії Вишневецького як виразника польсько-шляхетської ідентичності. Цей момент $є$ показовим у тексті в силу авторського зосередження на проблемі окреслення національної тожсамості не на етнічній, а на релігійній складовій, котра постає основою „уявленої спільноти” (Бенедикт Андерсон) та відображає певну місійність національного буття:

[...] позаботимся сначала, панове, не о своей утробе, а о благе великой нашей католической церкви. Которая одна только может сплотить нашу отчизну. [...] употребим все наши усилия на расчищения путей в дебрях схизмы, чтобы могли по ним проникнуть из Рима лучи и озарить светом заблубших $[\ldots]^{9}$.

У Михайла Старицького князь Ієремія, за походженням русин, обираючи католицизм ідентифікує себе як представника польської нації, тим самим увиразнює лінію протиставлення етнообразів за конфесійним принципом.

У романі Івана Нечуя-Левицького Князь Сремія Вишневецький (написано в 1896-1897рр.) Вишневецький, навпаки, позбавлений такого однозначного ідеологічного трактування, оскільки князь постає особою без чіткої національної визначеності і „[...] йому було байдуже, чи він українець, чи поляк:

\footnotetext{
${ }^{7}$ Там само.

${ }^{8}$ Н. Г о г о л ь, Тарас Бульба: сборник, Харьков 2008, с. 51.

${ }^{9}$ М. С т а р и ц к и й, Богдан Хмельницкий. Трилогия, кн. 1: Перед бурей, Киев 1991,
} c. 107. 
віра була задля його одна формальність, без котрої не можна було досягти до визначення для себе високої мети" ${ }^{\prime 10}$. Втім, проблема конструювання образу Іншого через призму віри у письменника також чітко окреслюється, але на прикладі стереотипних для українського письменства персонажів - єзуїтів, котрі маркуються в інфернальній семантичній палітрі як „демони спокусники" ${ }^{\prime 1}$. У Нечуя-Левицького образ єзуїта адсорбує окрім релігійного протистояння ще й асимілятивну політику Речі Посполитої денаціоналізації української шляхти. У подібній конотації з'являються ці персонажі в трилогії Старицького. Письменник саме 3 католицькою експансією пов'язує міжнаціональну напругу та негацію: „Они [єзуїти - О.К.] засеяли злобу и подожгли наше братское согласие, наш тихий рай"12. В останньому епізоді відчувається інтертекстуальна спорідненість із Шевченковим „тихим раєм”, що його „прийшли ксьондзи і запалили”. Українська історична проза 1880-1890-х років активно використовує релігійний фактор як данину вітчизняної історіографічної традиції для моделювання чіткої бінарної опозиції протиставлення власного етноіміджу Я та образу поляка як Іншого

Важливого значення у моделюванні образу поляка відіграє і соціальний чинник, оскільки в українській прозі XIX віку етнічні особливості представника польської нації асоціюються із шляхтою. До певної міри, це стосується і польського письменства, де особливе місце посідає ідеалізація аристократії як уособлення польської нації. У романі Генріка Сенкевича Вогнем $i$ мечем (1884-1888) саме шляхта як „народ лицарський” є виразником національно-патріотичної свідомості поляків. В українській ситуації основою національного буття природно постає козацтво, що впродовж XIX століття в колективній уяві, закріпленій текстуально, перетворилося на символ українства. Втім, формування козакоцентричної національної моделі пов'язано ще 3 козацькими хроніками. У літописі Григорія Граб'янки чітко окреслюється стратегія етнічного самоозначення через обрання нової назви етнічної спільноти: „народъ в Малороссійской странъ, глаголеный козаки" ${ }^{\text {"13 }}$. До подібного етимологічного зміщення щодо національного самоідентифікування підходить і Самійло Величко, вживаючи назви „Русь” та „козаки” у синонімічному, взаємодоповнюючому значенні: „[...] обидва, козаиько-руський [виділення наше - О.К.] і польський, преславні в Свропі народи [...]"14. Ентоні Д. Сміт відзначає, що справжній процес формування колективного національного чуття відбувається тоді, коли „члени спільноти починають усвідомлювати, ким вони $є$ колективно, й відчувати, що вони становлять спільноту з характерною

${ }^{10}$ I. Н е ч у й - Л е в и ц ь к и й, Князь Сремія Вишневецъкий, [в:] його ж, Князь Сремія Вишневецький. Гетьман Іван Виговський: Історичні романи, Київ 1991, с. 37.

${ }^{11}$ Там само, с. 17.

${ }^{12}$ М. С т а р и ц к и й, Богдан Хмельницкий. Трилогия, кн. 2: Буря, Киев 1991, с. 310-311.

${ }^{13}$ Гисторія... Г. Граб 'янки ..., зазнач. праця, с. 40.

${ }^{14}$ С. В е л и ч к о, Літопис, зазнач. праця, т. 1, с. 61. 
назвою $[\ldots]^{, 15}$. Козацька літописна традиція окреслює концепцію нації, у центрі якої домінантну роль займає козацтво, а українська белетристика XIX віку поглиблює і розширює іï смислове наповнення, лишаючи незмінною загальну козакофільську етноспрямованість. Однак у такій матриці національного самоокреслення вилученою опиняється українська шляхта, що хоча і найбільше піддавалась польським асимілятивним впливам, але ще лишалася у XVII столітті невід'ємною частиною національної спільноти. В авторських літературних стратегіях осмислення минулого саме ця соціальна група фактично опиняється поза межами української спільноти, корелюючись через соціальну складову із польською аристократією.

Тому конструювання образу чужого в українській літературі другої половини XIX століття, що здійснювалося через призму соціальної складової і грунтувалося на загальних естетичних принципах реальності, національності та народності, передбачає формування літератури, зрозумілої для широкого загалу, у першу чергу селянства.

В історичній прозі Нечуя-Левицького, Старицького та Мордовця іншування за соціальною ознакою стосується передовсім протиставлення поляк (пан, володар, шляхтич) - українець (селянин, кріпак, козак). Воно відповідало уявленням, закріпленим в колективній свідомості українства, i було розвинено творчою уявою письменників У такій бінарній системі образ Іншого маркується як визискувач, що гарантує індивідуальне та колективне благополуччя польського етносу через рабську працю українського народу. Антагонізм протистояння соціальних верств перетікає у національну площину: „по один бік річки стояла шляхетська Польща, по другий бік - задавлена народна й козацька Україна, ладна битись на смерть 3 своїм ворогом"16.

Однією із ключових тез протиставлення в українській історичній прозі 1880-1890-х років етнообразів Я та Іншого постає побутове іншування, котре позиціонує польський рафінований аристократизм та українське козацьке „спартанство”. Акцентування на схильності до розкоші у побуті шляхти перетворюється на аксіоматичну формулу моделювання поляка. Нечуй-Левицький пишноту польської аристократії сприймає як вияв національного духу цілого етносу, що, в умовах соціального та політичного домінування над українством, ілюструє втрату давніх лицарських традицій: „Розкіш вже запанувала в ті часи в Польщі. [Шляхта] вже втратила давню лицарську вдачу і давню простоту і стала зовсім не статковитою" ${ }^{\prime 7}$. До подібних трансформацій вдається і Данило Мордовець, абсолютизуючи любов до полювання та похвальбу рідкісними винами як особливі риси колективної ідентичності польської спільноти, що через аристократію зводяться до всього польського суспільства, незалежно від ієрархії, таким чином відсутній суспільний ієрархічний

\footnotetext{
${ }^{15}$ Е н т о н і Д. С м і т, зазнач. праця, с. 57.

${ }^{16}$ I. Н е ч у й - Л е в и ц ь к и й, Князь Сремія Вишневецький..., зазнач. праця, с. 226.

${ }^{17}$ Там само, с. 33.
} 
розподіл. В українській історичній прозі 1880-1890-х років образ поляка як Іншого тісно переплітається із ідеєю надмірного розкошування саме представників аристократії. Натомість образ поляка-простолюдина з'являється у таких текстах спорадично, але з виразним соціальним підтекстом. У трилогії Богдан Хмельничкий Михайло Старицький наголошує на можливості спільної боротьби козацтва та польського селянства проти шляхти як поневолювачів. Так, український гетьман закликає до повстання не лише українських простолюдів, а й польських, обіцяючи їм соціальне звільнення:

Разослал я [...] по всей земле универсалы к бедным собратьям ляхам, таким же подневольным у панства, как было и наше поспольство. Когда я поднял против угнетателей магнатов свой меч, то положил [...] освободить не только свой родной народ от польской кормиги, но и народ польський $[\ldots]^{18}$.

Прикметно, що в очах Хмельницького таке „звільнення”, хоча і засноване на соціальних протиріччях, але передбачає саме національно-патріотичну боротьбу, а не між станами суспільства. Втім така однобічна інтерпретація інших представників польської нації лише потверджує загальне негативне сприйняття поляка як шляхтича.

Для російськомовного роману Мордовця (Мордовцева) Царь и гетман антипольська риторика відіграє важливу концептуальну складову, оскільки негативна семантика ключового для твору образу Мазепи почасти грунтується на цій ідеї. Польське виховання майбутнього гетьмана в ідейній системі письменника стає основою моральної деградації особистості:

Лядскимъ ладаномъ прокуренъ Мазепа [...], ляхомъ смердитъ отъ всего духа мазепинского - такъ и остался старымъ королевскимъ пахолкомъ, что блюда лизалъ въ королевскихъ переднихъ $[\ldots]^{19}$.

Прикметно, що автор акцентує увагу на подвійній ідентичності Мазепи, де фатальну роль відіграла саме штучно прищеплена матір'ю польська тожсамість („,...] мать, вспоенная немножко молокомъ польской культуры, мечтала выработать изъ свого сынка «уродзонего панича» съ лоском, граціей и манерами отборнаго паньства" ${ }^{\text {"20 }}$ ). Цей епізод є показовим, оскільки підкреслює проблему протиставлення „спартанства” російських та українських представників (Петро I, Палій) манірності польської шляхти і Мазепи відповідно, що відбиває загальну колоніальну спрямованість трактувати Іншого як слабкого, якого необхідно підкорити. Така оптика метропольної репрезентації „перифеpiï” переміщає в середину імперської системи український етнос, лишаючи на маргінесах представників польської нації. Подібні характеристики присутні

${ }^{18}$ М. С т а р и ц к и й, Богдан Хмельницкий. Трилогия, кн. 3: У пристани, Киев 1991, c. $570-571$.

${ }^{19}$ Д. М о р д о в ц е в, Царь и гетман, [в:] його ж, Полное собраніе историческихъ романовъ, повестей и разсказов, кн. 8, Санкт-Петербург 1914, с. 64.

${ }^{20}$ Там само, с. 178 
і в романі Нечуя-Левицького Князь Сремія Вишневецький, у котрому абсолютизується польська аристократична манірність як риса слабкості:

Шляхта й великі пани тоді так впали, так розм'якинились од розкоші через панщину й неволю хлопів, що між ними князь Сремія був герой, бо ще вдержав прості українські давні норови ${ }^{21}$.

Відтак для української історичної прози виразне наголошення на культивованій примхливості та побутовій рафінованості шляхти відіграє роль своєрідного маркера мілітарної неповноцінності польського лицарства. Отож, антиколоніальна стратегія українських авторів передбачає іншування поляків в аксіологічній матриці слабкості, тим самим намагаючись підкреслити в образі Іншого риси певної нижчості стосовно козацько-селянського етноіміджу українця.

Як уже зазначалося вище, соціальний чинник іншування вилучає з колективного образу українства власну аристократію, маргіналізуючи іï та корелюючи з польською шляхтою. Побутова інакшість вибудовує біполярний світ існування козацтва та шляхти. У Нечуя-Левицького світоглядна зорієнтованість власної шляхти на Європу привносить в українську ситуацію не інтелектуальну просвіченість, а соціально-побутову іншість, що сприймається як ознака чужинності, польськості. Олеся Виговська, героїня роману Гетьман Іван Виговський (1899), через вишукане вбрання намагається підкреслити власну відмінність щодо одягу козацьких жінок:

[...] вона вже гадала в думці, яку собі французьку сукню пошити для парадного в’їзду в Чигирин, щоб вразити жінок козацьких старшин, котрі вбирались в кунтуші, в жупани, в плахти та в намітки ${ }^{22}$.

Однак це спонукає до окреслення образу гетьманші-шляхтянки як прихильниці польської культури, що провокує констатування іiї певної „неповноцінності” для української громади.

У негації образу поляка важливе значення відіграє і мілітарне польськоукраїнське протистояння. В історичній прозі Нечуя-Левицького та Старицького особливе місце відводиться польській жорстокості та садистським розправам над українським селянством та козаками. У трилогії Старицького подаються через призму козацького сприйняття розгорнуті картини знищення військами гетьмана Потоцького мирного українського населення під час козацької війни 1637-1638 років: „Посылает [Потоцький - О.К.] войска и на сем верств в окружности выжигает все до тла, вырезывает без сожаления всех - стариков, женщин, неповинных детей...,23. Нечуй-Левицький, у свою чергу, наголошує на особливо жорстокому винищенні українства князем Єремією

${ }^{21}$ I. Н е ч у й - Л е в и ц ь к и й, Князь Сремія Вишневецький..., зазнач. праця, с. 246.

${ }^{22}$ I. Н е ч у й - Л е в и ц ь к и й, Гетьман Іван Виговський, [в:] його ж, Князь Сремія Вишневецький..., зазнач. праця, с. 354.

${ }^{23}$ М. С т а р и ц к и й, Богдан Хмельницкий. Трилогия, зазнач. праця, кн. 1, с. 89. 
Вишневецьким у 1648 році, надаючи цим епізодам особливого інфернального звучання: „Здавалось, ніби Єремія вернувся в ті давні часи і приносив страшні жертви Ваалові та Молохові: то були й справді жертви - польським панам" ${ }^{24}$. Фізичне знищення українства постає своєрідним національним кредо польської нації: „Бити козаків, різати українських хлопів та пити вино - це найбільша наша справа, це наше щастя", - такою сентенцією Нечуй-Левицький наділяє гетьмана Потоцького ${ }^{25}$.

Українські автори не замовчують і козацьке насильство, однак воно набирає певного ідеологічного забарвлення й постає виключно як своєрідна відповідь на польський виклик, а помста і відплата природно вписуються в загальний образ козака-захисника Вітчизни:

Козаки вместе с мещанами, ворвавшимися в браму крестьянами бросались за ними [поляками та євреями - О.К.] по пятам, настигали их на бегу, хватали их на порогах жилищ, врывались сквозь выломаные двери [...]. Ни мольбы, ни проклятия, ни слезы, ни вопли детей не смягчали и не трогали ожесточенных долгими истязаниями сердец $^{26}$.

Однак подекуди і автор (Михайло Старицький) не знаходить виправдання козацькому бездумному свавіллю та знищенню усього неукраїнського. Особливо вражаючою у цьому контексті постає розправа Кривоноса у Махнівці, що перетворюється на своєрідний кривавий бенкет:

три дня ватаги его [Кривоноса - О. К.] [...] бесновались в Махновке и окрестностях, истребляя немилосердно всякого, кто, по несчастью, случайно был в польском кунтуше, или в бороде, или промолвил нерусское слово ${ }^{27}$.

Хоча в історичній прозі 1880-1890-х років спостерігається загальна стереотипізація поляка як чужого і ворога, проте в текстах і Нечуя-Левицького, і Старицького присутні й певні альтернативні стратегії маркування сусіднього етносу. У літературі XIX віку з'являються спорадичні спроби подивитися на польську націю не через призму ворожості, а спорідненості. Ідилічні версії Тараса Шевченка про оновлення польсько-українського „тихого раю” чи дражливі тези Пантелеймона Куліша у Крашанці русинам і полякам (1882) про „страшного ворога” великого Нетяма, „що криецця в Руському народі” та руйнує міжнаціональне порозуміння ${ }^{28}$, частково адсорбуються історичною белетристикою кінця XIX ст. Поза картинами антагоністичного протистояння окреслюється перспектива порозуміння та мирного співіснування двох етносів. Показовим у цьому контексті є моделювання цілої когорти персонажів поля-

\footnotetext{
${ }^{24}$ І. Н е ч у й - Л е в и ц ь к и й, Князь Сремія Вишневечький..., зазнач. праця, с. 167-168.

${ }^{25}$ Там само, с. 82.

${ }^{26}$ М. С т а р и ц к и й, Богдан Хмельницкий. Трилогия, зазнач. праця, кн. 3, с. 91.

27 Там само, с. 282.

${ }^{28}$ П. К у л і ш, Краманка русинам и полякам на Великдень 1882 року, Львів 1882,
} c. 38 . 
ків у трилогії Старицького Богдан Хмельниикий, котрі намагаються окреслити перспективу толерантного співжиття поляків і українців. Особливо символічного наповнення набуває образ польського шляхтича Грабовського, що свідомо обирає українську ідентичність та стає козаком Грабиною. А відтак усе його „нове” життя перетворюється на спокутування гріхів, вчинених у минулому перед Україною: „Укоротил господь мой век, не дал сподвижничеством загладить мои вины. Так поверни ты [Хмельницький - О.К.], и за мою душу отслужи Украйне и богу...”29. Втім і ціла когорта польських політичних діячів (Радзієвський, Оссолінський) на чолі з королем Владиславом у Старицького постають прихильниками міжнаціональної дружби та братерства. Однак домінуючим все-таки у романістиці і Івана Нечуя-Левицького, і Михайла Старицького, i Данила Мордовця є моделювання поляка як Іншого, чужого, що демонструє свою зверхність та зневагу до всього українського.

Загалом стратегії конструювання гетерообразів поляків у вітчизняній історичній прозі глибоко защеплені на загальнонаціональних пошуках етнічної ідентичності українства, що особливо загострилися наприкінці XIX століття. У такій ситуації репрезентація Іншого в історичній ретроспективі дозволяе чіткіше окреслити автоімідж через призму протиставлення з сусідніми етносами та підкреслення відмінностей національного буття двох народів на різних рівнях. Саме у бінарних моделях „свій-чужий” проявляється антиколоніальний наратив історичної белетристики, що, у замаскованій чи відкритій формах, децентрує російське та польське домінування у літературних візіях минулого, артикулюючи водночас автономність та самодостатність української „уявленої спільноти" (Бенедикт Андерсон).

\footnotetext{
${ }^{29}$ М. С т а р и ц к и й, Богдан Хмельницикий. Трилогия, зазнач. праця, кн. 1, с. 314.
} 